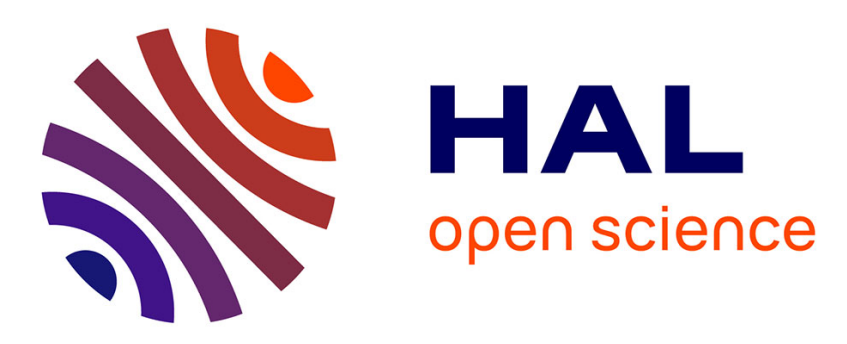

\title{
Variability of lactic acid production, chemical and microbiological characteristics in 24-hour Parmigiano Reggiano cheese
}

Marcela Santarelli, Benedetta Bottari, Massimo Malacarne, Camilla Lazzi, Stefano Sforza, Andrea Summer, Erasmo Neviani, Monica Gatti

\section{To cite this version:}

Marcela Santarelli, Benedetta Bottari, Massimo Malacarne, Camilla Lazzi, Stefano Sforza, et al.. Variability of lactic acid production, chemical and microbiological characteristics in 24-hour Parmigiano Reggiano cheese. Dairy Science \& Technology, 2013, 93 (6), pp.605-621. 10.1007/s13594-013-0135-4 . hal-01201445

\section{HAL Id: hal-01201445 \\ https://hal.science/hal-01201445}

Submitted on 17 Sep 2015

HAL is a multi-disciplinary open access archive for the deposit and dissemination of scientific research documents, whether they are published or not. The documents may come from teaching and research institutions in France or abroad, or from public or private research centers.
L'archive ouverte pluridisciplinaire HAL, est destinée au dépôt et à la diffusion de documents scientifiques de niveau recherche, publiés ou non, émanant des établissements d'enseignement et de recherche français ou étrangers, des laboratoires publics ou privés. 


\title{
Variability of lactic acid production, chemical and microbiological characteristics in 24-hour Parmigiano Reggiano cheese
}

\author{
Marcela Santarelli • Benedetta Bottari • Massimo Malacarne • \\ Camilla Lazzi • Stefano Sforza • Andrea Summer • \\ Erasmo Neviani • Monica Gatti
}

Received: 2 July 2012 /Revised: 4 April 2013 /Accepted: 5 April 2013 /

Published online: 13 June 2013

(C) INRA and Springer-Verlag France 2013

\begin{abstract}
The achievement of a sufficient acidity level by starters at early stages of manufacture is essential for a good quality Parmigiano Reggiano (PR) cheese. In this work, the chemical parameters and microbial characteristics of 18 PR cheeses during the moulding phase were analysed to determine how the microbial growth takes place conditioning acidification performances. Based on the mean values of lactic acid content, two groups of cheeses were observed. High numbers of culturable thermophilic bacteria and in particular Lactobacillus helveticus able to metabolise galactose but also grow faster in the cheese appeared to be essential conditions to achieve adequate lactic acid content. On the other hand, low acidification and residual galactose, as observed in the second group, may be associated with a lower amount of metabolically active L. helveticus and higher relevance of Streptococcus thermophilus contents in the cheese. While culturable thermophilic bacteria were fundamental for higher lactic acid production, non-culturable cells did not seem to contribute to the acidification.
\end{abstract}

Keywords Parmigiano Reggiano unripened cheese · Natural whey starter · Acidification level · Microbial development · Chemical parameters · Lactobacillus helveticus $\cdot$ Streptococcus thermophilus

\section{Introduction}

Parmigiano Reggiano (PR) is a protected designation of origin (PDO) Italian hard-cooked cheese, ripened for a period of at least 1 year, during which major microbiological and

M. Santarelli, B. Bottari and M. Malacarne contributed equally to this work.

\footnotetext{
M. Santarelli $\cdot$ B. Bottari $\cdot$ M. Malacarne $\cdot$ C. Lazzi · S. Sforza $\cdot$ A. Summer $\cdot$ E. Neviani M. Gatti $(\bowtie)$

Department of Food Science, University of Parma, Viale delle Scienze 11/A, 43124 Parma, Italy

e-mail: monica.gatti@unipr.it
} 
biochemical changes occur. Raw and partially skimmed cow's milk supplemented with a natural thermophilic starter culture are the main sources of lactic acid bacteria (LAB) in this cheese. The starter culture, consisting of naturally acidified cheese whey, is composed mainly of different strains of Lactobacillus helveticus, Lactobacillus delbrueckii subsp. lactis and by a minority of Streptococcus thermophilus and Lactobacillus fermentum (Bottari et al. 2010). During traditional cheese manufacture, the high cooking temperature (approximately $55^{\circ} \mathrm{C}$ ) selects a thermophilic flora that is crucial for the cheese ripening; these species act directly through their enzymes and indirectly through acidification (De Dea et al. 2008; Gatti et al. 2008). This thermophilic microbiota, which remains in the cooked whey, originates the natural whey starter culture (NWC) that is used in the next day's cheese-making, maintaining a microbiological linkage among batches of production. After vat extraction of the cheese mass, its transformation proceeds with a moulding that may last up to 2 days (http://www.parmigiano-reggiano.it). It is during this phase and during the first $24 \mathrm{~h}$ in particular that acidification occurs and the main biochemical processes take place in the cheese together with the highest growth of the starter thermophilic bacteria (Fox et al. 1993). Highly acidifying thermophilic LAB in the natural whey starter are the main organisms responsible for this process in which suitable fermentation of lactose leads to lactic acid production. In PR, as in other Grana type cheeses, the LAB from the natural whey starters require approximately 5-20 h, depending on the zone of the cheese, to acidify the curd (Mucchetti and Neviani 2006). In fact, it is well known that the cheese-making technology and the dimension of the wheel (22-24 cm high, 40-45 cm diameter) of these long-ripened cheeses lead to differential development of bacterial growth between the inner and the outer regions of the wheel. Thus, the lactic acid production and, correspondingly, the drop in $\mathrm{pH}$ at the appropriate rates and times are key steps in the manufacture of a good-quality cheese. Acidification inhibits the growth of pathogens and foodspoilage bacteria and also enhances the expulsion of whey from the cheese mass during the cheese-making process, producing cheese with the desired moisture level (Mucchetti and Neviani 2006; Powell et al. 2011).

In the first hours of PR cheese manufacturing, slow acidification and the presence of residual fermentable sugar, such as galactose, may occur. Moreover, the large size of a cheese wheel (i.e. $50 \mathrm{~kg}$ ) leads to a slow cooling, creating a gradient between internal and external zones during the overall moulding phase. In particular, at $24 \mathrm{~h}$ after vat extraction, temperatures can reach $35{ }^{\circ} \mathrm{C}$ and $27{ }^{\circ} \mathrm{C}$ in the internal and external zones, respectively (Giraffa et al. 1998). In the absence of antagonist microbiota, these are favourable conditions for the growth of undesirable bacteria that, if present in the raw milk, can lead to fermentations with gas formation with structural defect consequences to the cheese. Spoilage bacteria such as Clostridium butyricum, Clostridium tyrobutyricum, Clostridium sporogenes, coliforms and yeasts can find optimal conditions for their growth, causing early and late blowing in PR cheese (Bassi et al. 2009). Moreover, also early gas, mainly $\mathrm{CO}_{2}$, can occur due to the growth of heterofermentative, non-starter LAB (NSLAB) able to metabolise residual galactose (Mucchetti and Neviani 2006).

As stated above, the achievement of a sufficient acidity level by starters at a proper time is essential for a good-quality PR cheese. Thus, the aim of this work was to evaluate the level of acidification of PR cheese at $24 \mathrm{~h}$ after vat extraction, during the moulding phase, to correlate that level to microbial development. To reach this goal, 
different PR cheeses were subjected to chemical and microbiological analyses. For microbial growth evaluation, different methodological approaches were used.

\section{Materials and methods}

\subsection{Cheese manufacturing}

Eighteen PR cheeses were sampled from seven different dairies in the PDO cheese production area. Five dairies supplied two cheeses, and two dairies four cheeses. PR cheeses (33-35 kg) were made according to the method approved by the Consortium (Council Regulation, 1992; http://www.parmigiano-reggiano.it). Vats (copper tanks) of $1,200 \mathrm{~L}$ capacity were filled with $1,100 \mathrm{~kg}$ of raw cow's milk obtained by combination (1:1) of partially skimmed evening milk and whole morning milk. The milk from the evening milking was partially skimmed after overnight natural creaming $\left(8-10 \mathrm{~h}\right.$ at $\left.12-18{ }^{\circ} \mathrm{C}\right)$. The natural whey cultures (NWC) used as starters $(2.5-3.2 \% \mathrm{v} / \mathrm{v})$ were obtained by incubating the cooked whey of the previous day's cheese-making at a gradient of temperature from approximately $50{ }^{\circ} \mathrm{C}$ to $35-20{ }^{\circ} \mathrm{C}$ for $18-24 \mathrm{~h}$. Calf rennet powder was added, and coagulation was performed at $32-35^{\circ} \mathrm{C}$ ( $1 \mathrm{~mL}$ coagulates $1 \mathrm{~L}$ milk at $35^{\circ} \mathrm{C}$ in $4 \mathrm{~min}$ ). After the coagulation, the curd was cut, then stirred and cooked for $5-15 \mathrm{~min}$ at $54-56^{\circ} \mathrm{C}$. After waiting $40-80 \mathrm{~min}$ to allow precipitation of the broken-up curd particles, the resulting cheese mass was extracted from the vat and cut into two twin wheels of approximately $38 \mathrm{~kg}$ each. The wheels were placed into moulds and were moulded for $48 \mathrm{~h}$ before being salted.

\subsection{Cheese samples}

Samples of cheese were collected aseptically at $24 \mathrm{~h}$ after vat extraction, during the moulding phase, and were kept at $4{ }^{\circ} \mathrm{C}$ until arrival at the laboratory. Representative portions of internal (i.e. central) and external (i.e. $\sim 0.5 \mathrm{~cm}$ from the cheese rind) zones were obtained from these cheese sections. To obtain a sample representative of the whole wheel, the two portions were mixed in equal masses and grated before the analysis. As soon as the samples arrived, they were subjected to microbiological analysis, moisture and $\mathrm{pH}$ determinations and stored at $-20{ }^{\circ} \mathrm{C}$ for further analysis within 2 days.

\subsection{Microbial counts}

Ten grams of the grated cheese samples were suspended in $90 \mathrm{~mL}$ of 20 g.L $\mathrm{L}^{-1}$ of trisodium citrate ( $\mathrm{pH}$ 7.5) (Sigma-Aldrich, St. Louis, MO, USA) and homogenised for $2 \mathrm{~min}$ in a blender (Seward, London, UK) at $230 \mathrm{rpm}$. Serial decimal dilutions in sterile quarter-strength Ringer solution (Oxoid, Basingstoke, UK) were made and spread-plated on the following media and incubated under the following conditions: MRS (Man Rogosa Sharpe) agar, pH 5.4 (Oxoid), at $42{ }^{\circ} \mathrm{C}$ and $25^{\circ} \mathrm{C}$ for $72 \mathrm{~h}$ (for the recovery of thermophilic and mesophilic lactobacilli, respectively) under anaerobic conditions (Anaerogen ${ }^{\mathrm{TM}}$; Oxoid); M17 agar (for the recovery of streptococci) (Oxoid) at $42{ }^{\circ} \mathrm{C}$ for $72 \mathrm{~h}$ under aerobic conditions and whey agar medium (WAM) 
(Gatti et al. 2003) at $42{ }^{\circ} \mathrm{C}$ for $72 \mathrm{~h}$ under anaerobic conditions (Anaerogen ${ }^{\mathrm{TM}}$; Oxoid) (for enumeration of lactic acid bacteria arising from the NWC). Plates were made in triplicate and results were expressed as log cfu per gram of cheese.

Additionally, an aliquot $(15 \mathrm{~mL})$ of each cheese homogenate in trisodium citrate was used for total and viable direct microscopic counts. The LIVE/DEAD Baclight ${ }^{\mathrm{TM}}$ Bacterial Viability kit (Molecular Probes, Eugene, OR, USA) was used according to the manufacturer's instructions. The cheese homogenates $(15 \mathrm{~mL})$ were centrifuged $\left(10,000 \mathrm{rpm}, 10 \mathrm{~min}, 4{ }^{\circ} \mathrm{C}\right)$. Each resulting pellet was washed twice in $15 \mathrm{~mL}$ of 20 g. $\mathrm{L}^{-1}$ sodium citrate (pH 7.5) (Sigma-Aldrich), then resuspended in $15 \mathrm{~mL}$ of sterile water and 10-fold diluted. Subsequently, $1 \mathrm{~mL}$ of each sample was used for viability counts as directed by the supplier. Samples stained with LIVE/DEAD were filtered onto black polycarbonate filters $(0.2 \mu \mathrm{m}$ pore size) (Millipore Corp., Billerica, MA, USA), visualised using an epifluorescence microscope (Nikon 80i, Tokyo, Japan) and counted as described by Bottari et al. (2010). Three separate replicates were examined for each sample.

\subsection{Determination of cheese community structure}

Microbial composition was evaluated by fluorescence in situ hybridisation (FISH) and length heterogeneity-PCR (LH-PCR).

\subsubsection{FISH}

FISH was performed on the 10 -fold dilutions of the cheese samples as previously described by Bottari et al. (2010). The Lbh1 FITC-labelled probe specific for $L$. helveticus and the St4 Cy3-labelled probe specific for S. thermophilus were used. Both probes were synthesised and labelled by Eurofins MWG (Ebersberg, Germany). After addition of $10 \mu \mathrm{L}$ of the hybridisation buffer $\left(0.9\right.$ mol. $\mathrm{L}^{-1} \mathrm{NaCl}, 0.01 \%$ SDS, 20 mmol. $\mathrm{L}^{-1}$ Tris- $\mathrm{HCl}$, pH 7.2, 45\% formamide) containing $10 \mathrm{ng}$ of each probe, slides were incubated in a dark humid chamber at $45{ }^{\circ} \mathrm{C}$ for $4 \mathrm{~h}$. Slides embedded in mounting oil were evaluated using a Nikon Eclipse 80i epifluorescence microscope (Nikon, Tokyo, Japan) equipped with a C-SHG1 100-W mercury lamp.

\subsubsection{DNA extraction and LH-PCR}

To obtain information about the community members in the cheese samples, genomic DNA was extracted from the cheese samples and subjected to LH-PCR fingerprinting analysis. Five grams of grated cheese was mortared, and $450 \mathrm{mg}$ was used for DNA extraction using the General Rapid Easy Extraction System DNA kit (InCura S.r.1., Cremona, Italy) according to the manufacturer's instructions.

The V1 and V2 16S rRNA gene regions were amplified using primers $63 \mathrm{~F}$ and 355R (Lazzi et al. 2004). The forward primer was $5^{\prime}$ end-labelled with 6carboxyfluorescein (6-FAM) dye. Amplicons were then separated by capillary electrophoresis in an automated sequencer (Applied Biosystems, Foster City, CA, USA). The PCR and capillary electrophoresis conditions were as described by Bottari et al. (2010). The fragment sizes (base pairs) were determined using GeneMapper software version 4.0 (Applied Biosystems) and the local Southern method to generate a sizing 
curve from the fragment migration of the internal size standard (GS500 LIZ ${ }^{\circledR}$; Applied Biosystems) using a threshold of 150 fluorescence units. Amplicon lengths were attributed to bacterial species according to published LH-PCR databases (Gatti et al. 2008; Lazzi et al. 2004).

\subsection{Compositional analyses}

$\mathrm{pH}$ measurements were performed using a potentiometer (Crison Instruments, Barcelona, Spain) and measuring directly in the cheese paste. Moisture content was determined by drying the sample at $102{ }^{\circ} \mathrm{C}$ (IDF 4A 1982), and fat was measured using Gerber's method as modified by Siegfeld (Savini 1946). Ash content was determined for the cheese and for water-soluble extracts of the cheese using the gravimetric method according to Savini (1946) after calcination of the cheese samples in a muffle furnace at $530{ }^{\circ} \mathrm{C}$. Water-soluble extracts of the cheese were obtained as reported by Metzger et al. (2001). Lactose, lactic acid and galactose contents were determined using an enzymatic test kit according to Giudici et al. (1996).

Total nitrogen, $\mathrm{pH}$ 4.6-soluble nitrogen $(\mathrm{SN}), 12 \%$ trichloroacetic acid-soluble nitrogen (TCASN) and 5\% phosphotungstic acid-soluble nitrogen (PTASN) fractions were separated using the procedure proposed by Gripon et al. (1975), and their values were assessed using the Kjeldahl method. Ammonia nitrogen $\left(\mathrm{N}-\mathrm{NH}_{3}\right)$ was determined according to Savini (1946). Using the nitrogen fractions, nitrogen values for the high molecular weight components (Peptone $\mathrm{N}=\mathrm{SN}-\mathrm{TCASN}$ ), low molecular weight peptides (Peptide $\mathrm{N}=$ TCASN - PTASN $-\mathrm{N}-\mathrm{NH}_{3}$ ) and free amino acids (Amino acid $\mathrm{N}=\mathrm{PTASN}$ ) were obtained.

\subsection{Amino acid determinations}

Each sample of grated cheese (10 g) was suspended in $45 \mathrm{~mL}$ of $0.1 \mathrm{~N} \mathrm{HCl}$. D,L-NorLeu $\left(0.5 \mathrm{~mL}\right.$ of a $5 \mathrm{mmol} . \mathrm{L}^{-1}$ solution) was added as an internal standard. The mixture was homogenised for 2 min with an Ultraturrax T 50 basic homogeniser (IKA, Staufen, Germany) and centrifuged for $60 \mathrm{~min}$ at $4{ }^{\circ} \mathrm{C}$ and $3,220 \times g$. The solution was filtered through a $45-\mu \mathrm{m}$ filter, and $3 \mathrm{~mL}$ of the filtrate was dried. The residue was dissolved in $2 \mathrm{~mL}$ of a $0.1 \%$ solution of formic acid and ultrafiltered for $30 \mathrm{~min}$ at $7,370 \times \mathrm{g}$ (using a molecular cut-off of $10 \mathrm{kDa}$ ). The filtrate was dried and suspended in $300 \mu \mathrm{L}$ of bidistilled water. The derivatisation reaction was carried out using $10 \mu \mathrm{L}$ of the solution and the AccQ-FluorTM reagent kit (Waters, Milford, MA, USA) following the manufacturer's instructions. The mixture was analysed by HPLC using an Alliance 2695 separation module at a flow rate of $1 \mathrm{~mL} \cdot \mathrm{min}^{-1}$, using an AccQ-Tag C18 column $(3.9 \times 150 \mathrm{~mm})$ thermostated at $37{ }^{\circ} \mathrm{C}$. Elution conditions were eluent A: AccQ-TagTM added to phosphate buffer in $1 \mathrm{~L}$ of bidistilled water, eluent $\mathrm{B}: \mathrm{CH}_{3} \mathrm{CN} / \mathrm{H}_{2} \mathrm{O} 60: 40$, gradient: $0-1$ min linear gradient from $100 \%$ to $97 \% \mathrm{~A}$, 1-13 min linear gradient from $97 \%$ to $93 \%$ A, 13-18 min linear gradient from $93 \%$ to $90 \% \mathrm{~A}, 18-38$ min linear gradient from $90 \%$ to $67 \% \mathrm{~A}, 38-51 \mathrm{~min}$ isocratic $67 \% \mathrm{~A}$, 51-52 min linear gradient from $67 \%$ to $0 \% \mathrm{~A}, 52-61 \mathrm{~min}$ isocratic $0 \% \mathrm{~A}$ and reconditioning (25 $\mathrm{min}$ ). Detection was performed using a Waters 2475 fluorimetric detector, $\mu_{\mathrm{abs}}=250 \mathrm{~nm}$ and $\mu_{\mathrm{em}}=395 \mathrm{~nm}$. Quantification was performed using a calibration curve obtained using the internal standard method. 


\subsection{Natural whey starter cultures}

Eighteen NWC used for each cheese production were also analysed. Aliquots $(10 \mathrm{~mL})$ of NWC were collected and kept at $4{ }^{\circ} \mathrm{C}$ until arrival to the laboratory. Serial decimal dilutions in sterile quarter-strength Ringer solution (Oxoid) were made for microbial counts. Samples were spread-plated on WAM (Gatti et al. 2003) and incubated at $42{ }^{\circ} \mathrm{C}$ for $72 \mathrm{~h}$ under anaerobic conditions (Anaerogen ${ }^{\mathrm{TM}}$, Oxoid). Plates were made in triplicate and results were expressed as log cfu per milliliter. Total and viable direct counts were carried out to $1 \mathrm{~mL}$ of a second-diluted NWC, previously washed twice with sterilised distilled water, according to the manufacturer's instructions (Molecular Probes). FISH analysis, DNA extraction and LH-PCR were performed as previously described by Bottari et al. (2010). pH was measured with a potentiometer and titratable acidity determined by titration with $0.25 \mathrm{M} \mathrm{NaOH}$ using the Soxhlet-Henkel method (Anon 1963). D-Lactic acid and L-lactic acid contents were determined using an enzymatic test kit according to Pellegrino et al. (1996).

\subsection{Statistical analysis}

Data were analysed using ANOVA multivariate (PASW statistics 18.0.0, Armonk, NY, USA) according to the following general linear model: $y_{i j}=\mu+\alpha_{i}+\varepsilon_{i j}$, where $y_{i j}=$ dependent variable, $\mu=$ common mean, $\alpha_{i}=$ effect of lactic acid content $i=1,2$ and $\varepsilon_{i j}=$ residual error. Significances of differences were tested using Fisher's LSD (least significant difference) method.

\section{Results}

The 18 samples of 24-h cheese were grouped on the basis of lactic acid content into LLA (low lactic acid, $\leq 1.8$ ) and HLA (high lactic acid, >1.8) groups, for which lactic acid was expressed as grams per $100 \mathrm{~g}$ of cheese dry matter (DM) (Table 1). Among the cheese samples examined, 7(39\%) belonged to the LLA group and $11(61 \%)$ to the HLA group. In particular, two dairies made cheeses that were included in LLA group, three dairies in HLA group and two dairies produced cheeses that belonged to both cheese groups.

\subsection{Cheese composition}

The basic compositions of the cheese samples are reported in Table 2. No differences between LLA and HLA cheeses were observed for moisture, protein and fat content (g.100 $\mathrm{g}^{-1}$ cheese DM). However, the LLA group was characterised by ash contents lower $(P \leq 0.05)$ than those of the HLA group. In addition, water-soluble ash (expressed as percent of cheese ash) was lower $(P \leq 0.05)$ in the LLA group.

The lactose, galactose and lactic acid contents $\left(\mathrm{mmol} . \mathrm{kg}^{-1} \mathrm{DM}\right)$ and $\mathrm{pH}$ values of the 24-h cheeses are shown in Table 2. Compared to HLA cheeses, LLA cheeses were characterised by higher $(P \leq 0.05)$ values for galactose and lower $(P \leq 0.05)$ values for lactic acid. The same cheeses were also analysed $12 \mathrm{~h}$ after moulding at vat extraction, and the lactic acid content was not different between the LLA and HLA cheese samples 
Table 1 The values of lactic acid content (as \% cheese dry matter, DM) recorded in the 18 cheese samples are reported
The average lactic acid content in cheese was $1.86 \mathrm{~g} .100 \mathrm{~g}^{-1}$. Samples with lactic acid content below the average value were assigned to LLA while those with a lactic acid above the average value were categorised as HLA

\begin{tabular}{lll}
\hline ID sample & $\begin{array}{l}\text { Lactic acid } \\
\left(\mathrm{g} .100 \mathrm{~g}^{-1} \mathrm{DM}\right)\end{array}$ & Classification \\
\hline 1 & 0.53 & LLA \\
2 & 0.94 & LLA \\
3 & 1.49 & LLA \\
4 & 1.67 & LLA \\
5 & 1.67 & LLA \\
6 & 1.70 & LLA \\
7 & 1.80 & LLA \\
8 & 1.90 & HLA \\
9 & 1.95 & HLA \\
10 & 1.95 & HLA \\
11 & 2.08 & HLA \\
12 & 2.19 & HLA \\
13 & 2.22 & HLA \\
14 & 2.22 & HLA \\
15 & 2.19 & HLA \\
16 & 2.28 & HLA \\
17 & 2.35 & HLA \\
18 & 2.35 & HLA \\
Average value & 1.86 & \\
\hline
\end{tabular}

$\left(52.16 \pm 14.42\right.$ vs. $\left.54.38 \pm 15.54 \mathrm{mmol} . \mathrm{kg}^{-1} \mathrm{DM}\right)$ (data not shown). The proportion of D-lactic acid (and thus also of L-lactic acid) was not different between HLA and LLA cheeses. Regarding acidification, the LLA and HLA group showed $12 \mathrm{~h}$ after moulding almost identical $\mathrm{pH}$ values (mean 5.420 \pm 0.200 and $5.444 \pm 0.060$, respectively) (data not shown), but differed significantly after $24 \mathrm{~h}(P \leq 0.05)$. The $\mathrm{pH}$ values were lower in HLA than in LLA cheeses, with an average difference of 0.18 units. No differences between nitrogen fractions of LLA and HLA cheeses were observed (data not shown), except for the ripening index ( $\mathrm{pH}$ 4.6-soluble nitrogen, as percent of total nitrogen) that was higher in HLA than in LLA cheeses $(P \leq 0.05)$.

\subsection{Amino acid composition}

Total free amino acid concentrations (expressed as milligrams per $100 \mathrm{~g}$ of cheese protein) were significantly higher in 24 -h cheese samples in the HLA group than those in the LLA group (Table 2). Moreover, significant differences could be detected in the concentrations of some amino acids such as Gly, His, Arg, Ala, Pro and Lys that were higher in HLA cheese samples. Their values ranged from $27 \%$ for Lys to $49 \%$ for His (data not shown). The content of free amino acids was also assessed for the same cheese samples just after the vat extraction $(12 \mathrm{~h})$. At that point of the cheese-making process, no differences in the contents of the single amino acids or their sum were observed between LLA and HLA cheeses (data not shown). 
Table 2 Composition and $\mathrm{pH}$ values of $24-\mathrm{h}$ cheeses according to lactic acid content [LLA, $\leq 1.8$; HLA, >1.8 g.100 $\mathrm{g}^{-1}$ cheese dry matter (DM)]

\begin{tabular}{|c|c|c|c|c|c|}
\hline \multirow[t]{2}{*}{ Composition } & \multicolumn{2}{|l|}{ LLA } & \multicolumn{2}{|l|}{ HLA } & \multirow[t]{2}{*}{$P^{\mathrm{b}}$} \\
\hline & Mean & $\mathrm{SD}^{\mathrm{a}}$ & Mean & $\mathrm{SD}^{\mathrm{a}}$ & \\
\hline Moisture (g.100 $\left.\mathrm{g}^{-1}\right)$ & 38.70 & 0.98 & 38.55 & 0.83 & $\mathrm{NS}^{\mathrm{c}}$ \\
\hline Protein (g.100 g $\left.\mathrm{g}^{-1} \mathrm{DM}\right)$ & 48.75 & 1.06 & 48.18 & 2.79 & NS \\
\hline Fat (g.100 $\left.\mathrm{g}^{-1} \mathrm{DM}\right)$ & 44.73 & 1.12 & 44.61 & 5.07 & NS \\
\hline Ash (g.100 $\left.\mathrm{g}^{-1} \mathrm{DM}\right)$ & 4.77 & 0.15 & 4.94 & 0.16 & $\leq 0.05$ \\
\hline Lactose (mmol. $\left.\mathrm{kg}^{-1} \mathrm{DM}\right)$ & 0.87 & 1.46 & 0.41 & 0.61 & NS \\
\hline Galactose (mmol. $\left.\mathrm{kg}^{-1} \mathrm{DM}\right)$ & 43.39 & 10.54 & 17.31 & 11.15 & $\leq 0.05$ \\
\hline Lactic acid (mmol. $\left.\mathrm{kg}^{-1} \mathrm{DM}\right)$ & 115.38 & 53.05 & 239.07 & 17.98 & $\leq 0.05$ \\
\hline D-Lactic acid (\%) & 47.21 & 4.79 & 39.08 & 11.44 & NS \\
\hline Ripening index ${ }^{\mathrm{d}}$ & 3.90 & 1.09 & 4.88 & 0.89 & $\leq 0.05$ \\
\hline Sum FAAs ${ }^{\mathrm{e}}\left(\mathrm{mg} .100 \mathrm{~g}^{-1}\right.$ of cheese protein) & 674.94 & 123.96 & 805.22 & 123.19 & $\leq 0.05$ \\
\hline Water-soluble ash/ash (\%) & 30.79 & 2.22 & 44.79 & 1.77 & $\leq 0.05$ \\
\hline $\mathrm{pH}$ & 5.401 & 0.154 & 5.220 & 0.196 & $\leq 0.05$ \\
\hline
\end{tabular}

${ }^{\text {a }}$ Standard deviation

${ }^{\mathrm{b}} P$ value

${ }^{\mathrm{c}}$ Not significant, $P>0.05$

${ }^{\mathrm{d}}$ Soluble nitrogen at $\mathrm{pH} 4.6 /$ total nitrogen (\%)

${ }^{\mathrm{e}}$ Free amino acids

Table 3 Microbial counts of 24-h cheese samples according to lactic acid content [LLA, $\leq 1.8$; HLA, >1.8 g.100 $\mathrm{g}^{-1}$ cheese dry matter]

\begin{tabular}{|c|c|c|c|c|c|c|}
\hline \multirow[t]{2}{*}{ Composition } & \multirow[t]{2}{*}{ Units of measurement } & \multicolumn{2}{|l|}{ LLA } & \multicolumn{2}{|l|}{ HLA } & \multirow[t]{2}{*}{$P^{\mathrm{b}}$} \\
\hline & & Mean & $\mathrm{SD}^{\mathrm{a}}$ & Mean & $\mathrm{SD}^{\mathrm{a}}$ & \\
\hline Total & Log cells.g ${ }^{-1}$ & 8.48 & 0.40 & 8.66 & 0.34 & $\mathrm{NS}^{\mathrm{c}}$ \\
\hline Mesophilic lactobacilli & Log cfu.g ${ }^{-1}$ & 1.44 & 1.02 & 1.52 & 0.77 & NS \\
\hline Thermophilic lactobacilli & Log cfu.g ${ }^{-1}$ & 6.95 & 0.50 & 8.21 & 0.38 & $\leq 0.05$ \\
\hline Streptococci & Log cfu.g ${ }^{-1}$ & 4.46 & 0.71 & 5.47 & 1.06 & $\leq 0.05$ \\
\hline Cultivable in WAM & Log cells.g ${ }^{-1}$ & 6.63 & 0.80 & 7.89 & 0.28 & $\leq 0.05$ \\
\hline Viable & Log cells.g ${ }^{-1}$ & 8.14 & 0.41 & 8.44 & 0.30 & NS \\
\hline Non-viable & Log cells. $g^{-1}$ & 8.18 & 0.42 & 8.19 & 0.45 & NS \\
\hline
\end{tabular}

Mesophilic lactobacilli: MRS at $25{ }^{\circ} \mathrm{C}$, in anaerobiosis; thermophilic lactobacilli: $\mathrm{MRS}$ at $42{ }^{\circ} \mathrm{C}$ in anaerobiosis, Streptococci population: M17 at $25{ }^{\circ} \mathrm{C}$, aerobiosis. WAM (whey agar medium) at $42{ }^{\circ} \mathrm{C}$ under anaerobic conditions for enumeration of lactic acid bacteria arising from natural whey starter. Total, viable and non-viable were performed by direct microscopic counts

${ }^{\text {a }}$ Standard deviation

${ }^{\mathrm{b}} P$ value

${ }^{\mathrm{c}}$ Not significant, $P>0.05$ 


\subsection{Microbial counts}

Direct microscopic counts showed high total cell numbers in all samples (greater than $8 \mathrm{log}$ cells. $\mathrm{g}^{-1}$ ), and no significant differences between the two groups were observed (Table 3). Cultivable mesophilic lactobacilli counts (evaluated in MRS agar, $\mathrm{pH} 5.4$, at $25^{\circ} \mathrm{C}$ ) were similar for both LLA and HLA samples. However, thermophilic lactobacilli counts (MRS at $42{ }^{\circ} \mathrm{C}$ ) showed significant differences between the LLA and HLA groups (Table 3). Moreover, both the streptococcus population and the WAM-cultivable thermophilic bacterial population, used for the enumeration of LAB arising from the NWC, showed differences $(P \leq 0.05)$ between the two groups of cheeses. Therefore, only thermophilic microbial counts in the three growth media (MRS, M17 and WAM) showed higher cell densities in the HLA cheese group. Viability counts were performed using fluorescence microscopy. In contrast to the cultivable counts, no significant differences were observed between the LLA and HLA groups.

\subsection{Determination of cheese community structure}

Bacterial community structures of the 24-h cheeses were characterised using LH-PCR and FISH. Among the 18 cheese samples, three different LH-PCR profiles were observed (Fig. 1). Profile A was characterised by peaks at $330 \pm 1$ bp (attributed to $L$. delbrueckii subsp. lactis or subsp. bulgaricus), 334 \pm 1 bp (L. helveticus) and double peaks at $342 \pm 1$ bp and $345 \pm 1$ bp (attributed to L. fermentum). A peak at $305 \pm 1$ bp was also detected (non-attributed).

Profile B was characterised by the presence of only two peaks at $330 \pm 1$ bp and $334 \pm 1 \mathrm{bp}$, attributed to L. delbrueckii subsp. lactis and L. helveticus species, respectively, according to the database. Finally, profile $C$ presented peaks at $330 \pm 1 \mathrm{bp}$ and $334 \pm 1 \mathrm{bp}$, attributed to L. delbrueckii subsp. lactis and L. helveticus, respectively, and a peak at $320 \pm 1 \mathrm{bp}$ attributed to $S$. thermophilus. Other peaks at $305 \mathrm{bp}$ and $323 \mathrm{bp}$ were also detected but not attributed to any species in the database.

Most cheese samples (45\%) were characterised by profile A and 33\% displayed profile $\mathrm{B}$, whereas profile $\mathrm{C}$ was revealed in $22 \%$ of the $24-\mathrm{h}$ cheese samples. No correlation between profile types and lactic acid content groups was observed. However, only profile $\mathrm{C}$ was represented by the HLA cheeses.

Bacterial identification using FISH analysis was performed using probes specific for viable $L$. helveticus and $S$. thermophilus species. The signal intensity of cells hybridised with oligonucleotide probes is directly related to the cellular rRNA content, which is a useful indicator of viability (Bottari et al. 2006). An evaluation of the relative abundance of the two targeted viable species was performed for each sample according to Bottari et al. (2010). Figure 2 shows two representative pictures of FISH analysis of LLA and HLA cheese groups. Red fluorescent cocci were $S$. thermophilus hybridised cells, bright green fluorescent rods were L. helveticus hybridised cells and dim green non-fluorescent rods cells were lactobacilli cells with very low metabolic activity. It was observed that the LLA cheese group was characterised by a majority of $S$. thermophilus hybridised cells with respect to $L$. helveticus hybridised cells with intense fluorescence. On the contrary, HLA cheese samples showed a majority of $L$. helveticus hybridised cells with respect to $S$. thermophilus hybridised cells. 

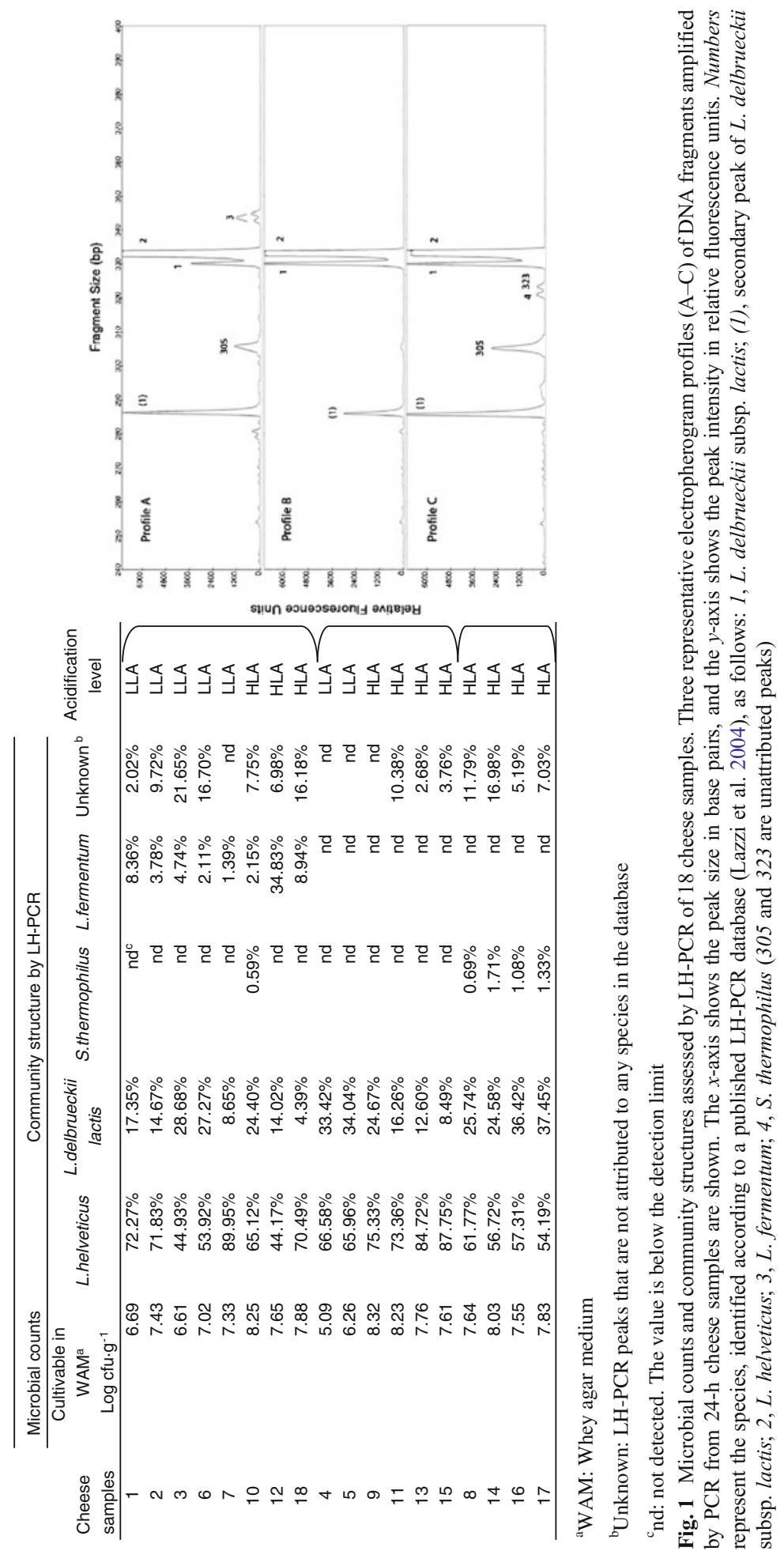
a FISH LLA

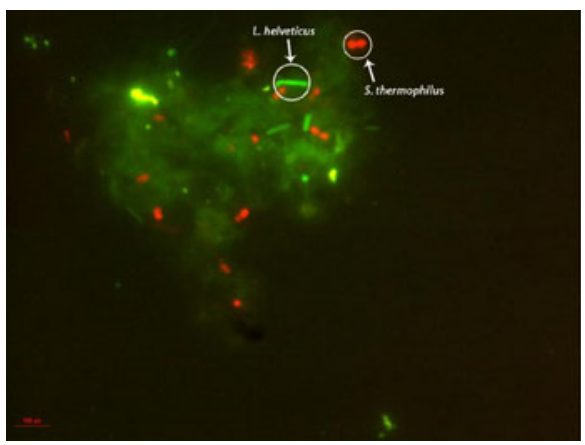

b FISH HLA

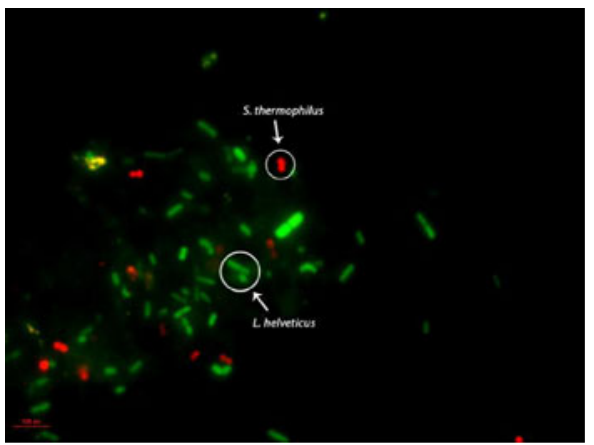

Fig. 2 FISH of two representative 24-h cheese samples (respectively sample 1 and sample 9) classified as LLA (a) and HLA (b). The simultaneous use of probes St4 (red label) and Lbh1 (green label) revealed the presence of a majority $(++)$ of hybridised $S$. thermophilus cells with respect to L. helveticus cells (a). A lower amount $(+)$ of hybridised $L$. helveticus cells was also present. While a relative majority $(++)$ of hybridised $L$. helveticus cells were revealed in HLA, a lower amount of hybridised $S$. thermophilus cells $(+)$ were also present (b)

\section{Discussion}

During the first $24 \mathrm{~h}$ of the moulding phase, acidification by conversion of lactose into lactic acid is the main biochemical process that takes place in cheese. Acid production at the appropriate rate and time is a key step in the manufacture of a goodquality cheese (Fox et al. 1993; Powell et al. 2011). In PR, the growth of the natural whey starter LAB is responsible for the acidity reached in cheese at $24 \mathrm{~h}$. The chemical parameters and microbial characteristics of the 18 PR cheeses, sampled from seven dairies at $24 \mathrm{~h}$ after vat extraction, were analysed in order to correlate their level of acidification to microbial development. The cheeses were divided into two groups according to their lactic acid contents detected at $24 \mathrm{~h}$ during moulding, termed LLA and HLA (low and high lactic acid content cheeses, respectively).

\subsection{Compositional differences between LLA and HLA cheeses}

Regarding the contents of moisture, fat and protein, the values were consistent with those reported by Panari et al. (2003) for PR cheese at 24-48 h after vat extraction. In addition to higher lactic acid content, HLA group was characterised by lower values for galactose and $\mathrm{pH}$ and higher contents of ash, water soluble ash and total amino acid in comparison with the LLA group. The lower $\mathrm{pH}$ values reported in the HLA group may be responsible for greater solubilisation of the calcium phosphate bound to their casein matrices (Lucey and Fox 1993) leading to higher proportions of watersoluble ash in those cheeses. The different extents of mineral solubilisation observed in this work may lead to differences in the evolution of cheese ripening in LLA and HLA cheeses (Lucey et al. 2005).

In a previous study, which was carried out on six PR cheeses at $23 \mathrm{~h}$ after vat extraction, Pecorari et al. (2003) reported lactic acid content and $\mathrm{pH}$ values comparable with those observed for HLA cheeses but clearly different when compared to LLA cheeses. Furthermore, in contrast to the present study, Pecorari et al. (2003) 
detected a lower amount of galactose $\left(0.009\right.$ g. $100 \mathrm{~g}^{-1} 23$-h cheese $)$ compared with the amount we found in the HLA group $\left(0.19\right.$ g. $\left.100 \mathrm{~g}^{-1}\right)$ and, in particular, in LLA cheeses $\left(0.48 \mathrm{~g} .100 \mathrm{~g}^{-1}\right)$. The residual galactose and lactose in early cheese can be the consequence of non-exhaustive fermentative activities of the starter LAB (Mucchetti and Neviani 2006). However, the natural whey starters utilised for each cheese production batch were considered of good quality with regard to their microbiological and chemical parameters (Table 4).

\subsection{Linking microbial characteristics to acidification level}

In this study, LLA and HLA cheeses showed similar lactose consumption but differed in their galactose content, which was significantly higher in the former group. This finding led us to hypothesise that the starter bacteria used to produce LLA cheeses might be characterised by LAB species or strains that consume galactose at low rates or that might not be able to consume it. Results obtained from the culture-dependent approach revealed significantly higher densities of thermophilic lactobacilli population able to grow in MRS and WAM media in HLA cheese group. Interestingly, in contrast to the higher cultivable counts in the HLA cheese group, no differences were found in the numbers of total, viable and non-viable cells between the two groups of samples. This similarity could be ascribed to the presence of bacteria that, although viable (detected only microscopically) in the sample, are not able to proliferate on culture media but could be capable of growth in cheese. However, the relevance of this population during ripening requires further study, and, being non-cultivable, they remain unknown.

For a deeper insight into microbial composition, culture-independent approaches were performed which helped to get more information. FISH and LH-PCR give different results, LH-PCR investigate total microbial DNA (that could arise from viable, non-viable and lysed cells, Gatti et al. 2008), while FISH detects ribosomal RNA of live cells. Thus, a thorough non-quantitative evaluation and comparison of both techniques was made. The dominant species found in the 24-h cheeses by LHPCR and/or FISH belonged to L. helveticus, L. delbrueckii subsp. lactis, S. thermophilus and L. fermentum according to Bottari et al. (2010). Most of these species can utilise galactose as a carbon source. However, it is known that galactose consumption is strain dependent in S. thermophilus (Robinson 2005). In this regard, although lactose is efficiently transported into the cell and subsequently hydrolysed by an intracellular $\beta$-galactosidase, many strains of $S$. thermophilus ferment only the glucose moiety of lactose, while galactose moiety is excreted into the medium in equimolar amounts with the lactose uptake (de Vin et al. 2005). De Vin et al. (2005) found that some $S$. thermophilus strains began to consume the galactose excreted into the medium only after lactose depletion, whereas others were unable to consume the galactose or they did so at different rates and to various extents but never to completion. In this work, the higher proportions of viable $S$. thermophilus hybridised cells, with respect to L. helveticus hybridised cells, revealed by FISH, support the hypothesis of a lower activity of $L$. helveticus, galactose positive species, and higher relevance of $S$. thermophilus strains in the residual carbohydrates found in LLA cheeses. Our hypothesis is supported by previous results of Mucchetti et al. (2002). These authors found that higher amounts of unmetabolised galactose remained at $24 \mathrm{~h}$ 


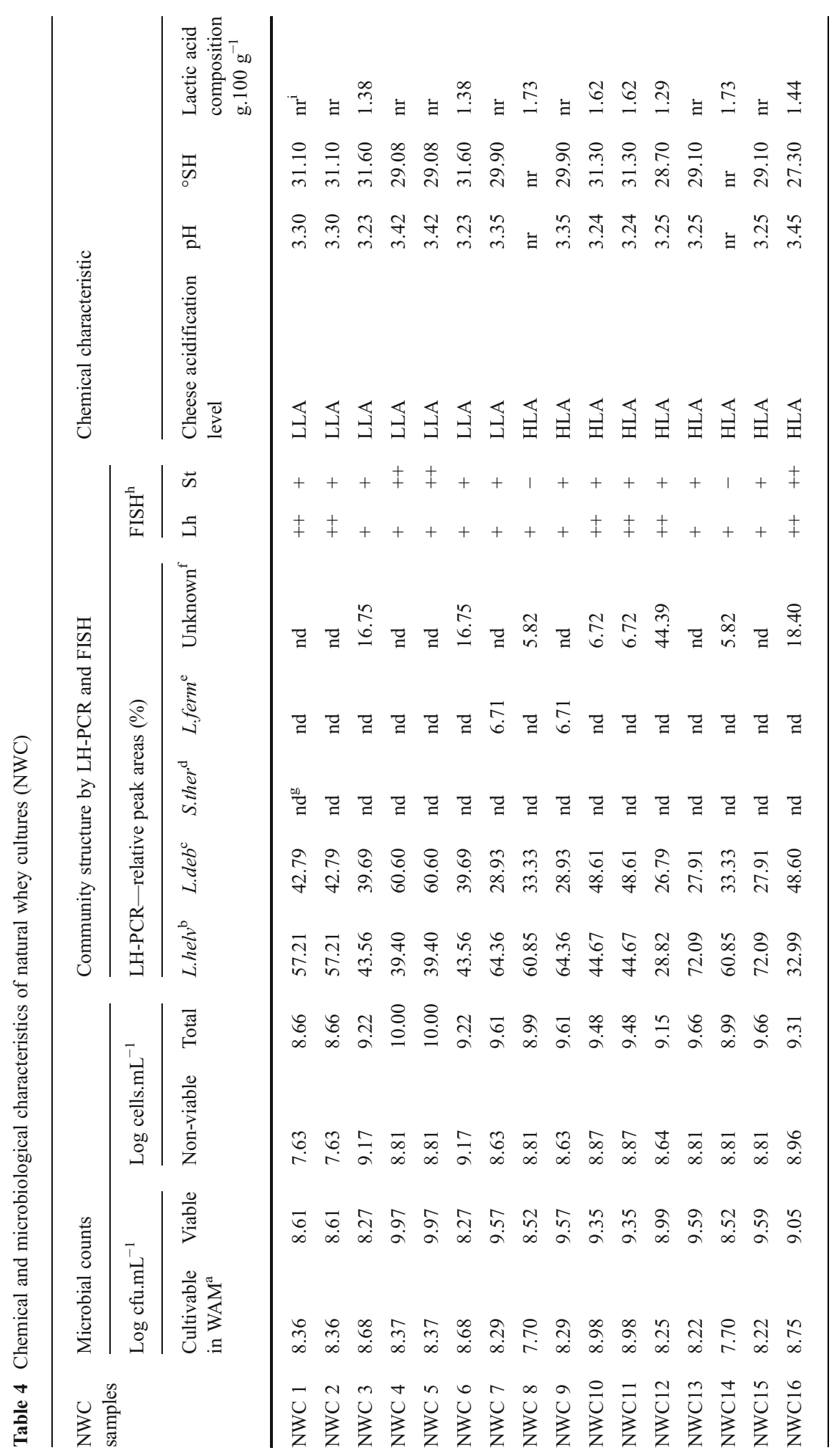




$$
1
$$


after vat extraction in an experimental mini-cheese made with a defined $S$. thermophilus strain as starter than by using (1) undefined natural cultures, (2) L. helveticus strains alone or (3) L. delbrueckii subsp. lactis strains alone (Mucchetti et al. 2002).

The change in relative lactic acid levels found at $24 \mathrm{~h}$ compared to $12 \mathrm{~h}$ was in good agreement with the presence of lower number of active cells of L. helveticus and a majority of $S$. thermophilus cells in the LLA cheese group. In fact, $S$. thermophilus is reported to acidify more rapidly than lactobacilli (Béal and Corrieu 1994; Mucchetti and Neviani 2006), but rapid acidification does not mean high acidification as demonstrated by Spinnler and Corrieu (1989), who concluded that the maximum acidification rate of $L$. helveticus was generally higher than that of $S$. thermophilus.

On the other hand, results lead to hypothesise that L. helveticus and other thermophilic lactobacilli are involved in the achievement of high acidification level. Using FISH, it was found that the HLA cheese group showed higher proportions of $L$. helveticus hybridised cells with respect to $S$. thermophilus. As L. helveticus is a highly acidifying species (Tuner and Martley 1983) also able to consume galactose, this result agrees with the higher average lactic acid contents and lower $\mathrm{pH}$ values found in those cheeses. Moreover, cultivable lactobacilli evaluated in MRS and WAM were significantly higher in HLA with respect to LLA cheese group. Thus, we could hypothesise that other lactobacilli able to grow in these culture media such as L. delbrueckii subsp. lactis could be responsible for the different acidification level.

Other findings led us to support the hypothesis of a higher population of $L$. helveticus during the early phase. The nitrogen contents and the individual free amino acids highlight some issues concerning cheese proteolysis from a quantitative and qualitative point of view. The ripening index and total amino acid contents were higher in HLA cheeses. Notably, the ripening index was already higher in HLA cheeses at vat extraction (data not shown). Therefore, the different degree of casein solubilisation reported here could be related to microbial development that had already occurred in the vat milk. The higher casein degradation observed in HLA cheese was associated with a majority of viable $L$. helveticus cells together with higher thermophilic lactobacilli counts in the HLA cheese group. Because different $L$. helveticus strains manifest different proteolysis rates (Gatti et al. 1999), the great variability among L. helveticus strains found not only in natural whey starters but also in cheese during moulding (Gatti et al. 2003; Giraffa and Neviani 1999) must also be considered.

\section{Conclusions}

The different lactic acid contents, found in two groups of PR cheese $24 \mathrm{~h}$ after vat extraction, were associated with different degrees of mineral solubilisation with possible repercussions for cheese rheology and, consequently, on the development of chemical, biochemical and microbial processes that take place throughout ripening.

Results obtained by the polyphasic approach used in this research allow to conclude that the presence of a high number of L. helveticus cells and/or other acidifying thermophilic lactobacilli, able to metabolise galactose and also grow faster in the cheese, appear to be essential conditions to achieve adequate lactic acid content and, thus, correct curd acidification. The presence of residual galactose was associated with low densities of thermophilic lactobacilli and higher proportion of fully 
active $S$. thermophilus with respect to L. helveticus. In this sense, even though their presence is not necessarily related to their development in the curd, the significance of $S$. thermophilus in the whey starter has to be reconsidered. In particular, the occurrence of $S$. thermophilus strains unable to completely consume galactose is likely an undesired component of the natural mix of LAB strains in whey starter.

Additional hypotheses may further explain differences in lactic acid contents, found in two groups of PR cheese $24 \mathrm{~h}$ after vat extraction. The biotype compositions of the whey starter LAB appear to be far more important than the species composition in ensuring their good performance. It should also be noted that residual galactose could also be due to inefficient natural whey starter acidification caused by phage activity not considered in this study.

Even if the approach used in this study provided technologically useful answers for the correct production of PR cheese, it may be extended to all hard-cooked cheeses produced with thermophilic natural cultures.

Acknowledgments Emilia Romagna Region is gratefully acknowledged for its support to this research through the Project L. R. 28/98 - P.S.A. 2007 ('Sieroinnesto per Parmigiano Reggiano, Funzionalità tecnologica del sieroinnesto per Parmigiano Reggiano'). The authors would like to thank Paola Vecchia (CRPA Reggio Emilia).

\section{References}

Anon (1963) Titratable acidity evaluation with the Soxhlet-Henkel (SH) method. Milchwissenschaft 18:520

Bassi D, Cappa F, Cocconcelli PS (2009) A combination of SEM technique and X-ray microanalysis for studying the spore germination process of Clostridium tyrobutyricum. Res Microbiol 160:322-329

Béal C, Corrieu G (1994) Viability and acidification activity of pure and mixed starters of Streptococcus salivarius ssp. thermophilus 404 and Lactobacillus delbrueckii ssp. bulgaricus 398 at the different steps of their production. LWT 27:86-92

Bottari B, Ercolini D, Gatti M, Neviani E (2006) Application of FISH technology for microbiological analysis: current state and prospects. Appl Microbiol Biotechnol 73:485-494

Bottari B, Santarelli M, Neviani E, Gatti M (2010) Natural whey starter for Parmigiano Reggiano: cultureindependent approach. J Appl Microbiol 108:1676-1684

De Dea LJ, Bernini V, De Lorentiis A, Pecorari A, Neviani E, Gatti M (2008) Parmigiano Reggiano cheese: evolution of cultivable and total lactic microflora and peptidase activities during manufacture and ripening. Dairy Sci Technol 88:511-523

de Vin F, Rådström P, Herman L, De Vuyst L (2005) Molecular and biochemical analysis of the galactose phenotype of dairy Streptococcus thermophilus strains reveals four different fermentation profiles. Appl Environ Microbiol 71:3659-3667

Fox PF, Law J, McSweeney PLH, Wallace J (1993) In: Fox PF, McSweeney PLH (eds) Advanced dairy chemistry, 3rd edn. Kluwer/Plenum, New York, pp 389-438

Gatti M, Contarini G, Neviani E (1999) Effectiveness of chemometric techniques in discrimination of Lactobacillus helveticus biotypes from natural dairy starter cultures on the basis of phenotypic characteristics. Appl Environ Microbiol 65:1450-1454

Gatti M, Lazzi C, Rossetti L, Mucchetti G, Neviani E (2003) Biodiversity in Lactobacillus helveticus strains present in natural whey starter used for Parmigiano Reggiano cheese. J Appl Microbiol 95:463-470

Gatti M, De Dea LJ, De Lorentiis A, Bottari B, Santarelli M, Bernini V, Neviani E (2008) Dynamics of whole and lysed bacterial cells during Parmigiano-Reggiano cheese production and ripening. Appl Environ Microbiol 74:6161-6167

Giraffa G, Neviani E (1999) Different Lactobacillus helveticus strain populations dominate during Grana Padano cheesemaking. Food Microbiol 16:205-210

Giraffa G, Rossetti L, Mucchetti G, Addeo F, Neviani E (1998) Influence of the temperature gradient on the growth of thermophilic Lactobacilli used as natural starters in Grana cheese. J Dairy Sci 81:31-36 
Giudici P, Masini G, Caggia C (1996) The role of galactose fermenting yeast in plain yogurt spoilage. Ann Microbiol Enzymol 46:11-19

Gripon JC, Desmazeaud MJ, Le Bars D, Bergère JL (1975) Étude du rôle des micro-organismes et des enzymes au cours de la maturation des fromages. II. Influence de la présure commerciale. Lait 55:502-516

IDF 4A (1982) Cheese and processed cheese. Determination of total solids content. International Dairy Federation, Brussels

Lazzi C, Rossetti L, Zago M, Neviani E, Giraffa G (2004) Evaluation of bacterial communities belonging to natural whey starters for Grana Padano cheese by length heterogeneity-PCR. J Appl Microbiol 96:481-490

Lucey JA, Fox PF (1993) Importance of calcium and phosphate in cheese manufacture. A review. J Dairy Sci 76:1714-1724

Lucey JA, Mishra R, Hassan A, Johnson ME (2005) Rheological and calcium equilibrium changes during the ripening of Cheddar cheese. Int Dairy J 15:645-653

Metzger LE, Barbano DM, Kindstedt PS (2001) Effect of milk preacidification on low fat Mozzarella cheese: III. Post-melt chewiness and whiteness. J Dairy Sci 84:1357-1366

Mucchetti G, Neviani E (2006) Microbiologia e Tecnologia lattiero-casearia. Qualità e sicurezza. Tecniche nuove, Milan

Mucchetti G, Locci F, Massara P, Vitale R, Neviani E (2002) Production of pyroglutamic acid by thermophilic lactic acid bacteria in hard-cooked mini-cheeses. J Dairy Sci 85:2489-2496

Panari G, Mariani P, Summer A, Guidetti R, Pecorari M (2003) Variazione della composizione e andamento della proteolisi del Parmigiano-Reggiano nel corso della maturazione in riferimento al profilo (centro e periferia) della forma. Sci Tec Latt-cas 54:199-212

Pecorari M, Gambini G, Reverberi P, Caroli A, Panari G (2003) Glycolysis in Parmigiano-Reggiano cheese during the first ripening phase. Sci Tec Latt-cas 54:149-162

Pellegrino L, De Noni I, Mannino S, Resmini P (1996) Galattosio residuo nel formaggio Grana Padano in fascera e possibile rilevamento mediante biosensore. Ind Latte 32:49-62

Powell IB, Broome MC, Limsowtin GKY (2011) In: Fuquay JW, Fox PF, McSweeney PLH (eds) Encyclopedia of dairy sciences, 2nd edn. Elsevier Science and Technology, Oxford

Robinson RK (2005) John Wiley \& Sons dairy microbiology handbook: the microbiology of milk and milk products, 3rd edn. Wiley Interscience, New York

Savini E (1946) Analisi del latte e dei latticini. Hoepli, Milan

Spinnler HE, Corrieu G (1989) Automatic method to quantify starter activity based on pH measurement. J Dairy Res 56:755-764

Tuner KW, Martley FG (1983) Galactose fermentation and classification of thermophilic Lactobacilli. Appl Environ Microbiol 45:1932-1934 